\title{
Screening of Human Proteins for Fluoride and Aluminum Binding
}

\author{
Md. Kamrul Hasan", , Saruar Alam1,"\#, Jovan Mirkovic², Md. Faruk Hossain²,* \\ ${ }^{1}$ Department of Biochemistry and Molecular Biology, University of Dhaka, Dhaka, Bangladesh; ${ }^{2}$ Department of Biological Sciences, St. \\ John's University, Queens, New York 11439; Md. Faruk Hossain - E-mail: farukbmb16@gmail.com; ${ }^{*}$ Corresponding author \#Equal \\ Contribution
}

Received January 17, 2018; Revised February 6, 2018; Accepted February 7, 2018; Published February 28, 2018

\author{
doi: $10.6026 / 97320630014068$
}

\begin{abstract}
:
Previous studies showed that prolonged exposure to fluoride ( $\mathrm{F}-$ ) and aluminum $\left(\mathrm{Al}^{3+}\right)$ ions is associated with numerous diseases including neurological disorders. They don't have any known biological function. But they can bind with proteins that interact with ions similar to them. Such unwanted interactions affect the normal biological function of the target proteins, as well as their downstream protein-protein interactions. Several studies show the detrimental effects posed by them including Alzheimer's disease. However, their target proteins have never been reported. Here, we have screened for the human protein targets subjected to F- and $\mathrm{Al}^{3+}$ interactions by using data-driven prediction tools. We have identified 20 different proteins that directly bind with them (10 interact with fluoride and 10 with aluminum). In addition, protein-protein interaction has been explored to find the proteins that indirectly interact with $\mathrm{F}^{-}$and $\mathrm{Al}^{3+}$. We have found 86 indirect targets for $\mathrm{F}^{-}$and 90 for $\mathrm{Al}^{3+}$. Furthermore, 19 common protein targets have been identified, including proteins (9 out of 19) associated with neurodegenerative disorders. However, wet lab experiments are beyond our scopes to validate the binding networks. Additional studies must be warranted.
\end{abstract}

Keywords: Fluoride, Aluminium, Neurodegenerative disorders, Human Health

\section{Background:}

Fluorine $(\mathrm{F})$ and aluminum $(\mathrm{Al})$ are widely used in additives. Fluorine commonly appears as fluoride ion (F-) that reacts with other positively charged cations [1]. Sodium fluoride, fluorosilicic acid or sodium fluorosilicate, and sodium mono fluorophosphate are the common compounds of fluoride being utilized. Humans are exposed to sodium fluoride $(\mathrm{NaF})$ from different sources including water, medicines, dental restorative materials, dental products (toothpaste and mouth rinses), pediatric supplements, beverages prepared with fluoridated water [2], tea, tobacco, pan masala (with tobacco and without tobacco) [3], and residues of pesticides, insecticides, and fertilizers [3]. Fluoride toothpaste is the most common source of fluoride ingestion into the human body. Research shows that $10 \%$ kids swallow toothpaste more than twofold the normal amount while brush their teeth [47].

Aluminium is the most abundant metal in nature having no known biological function [4]. It is an omnipresent element found ISSN 0973-2063 (online) 0973-8894 (print)

Bioinformation 14(2): 68-74 (2018) in all types of products including corn, salt, herbs, spices, tea, yellow cheese, cosmetics, and aluminium ware and containers. Compounds of aluminium are used to purify drinking water and to treat wastewater plants [5]. Aluminium compounds are used in many medicines and pharmaceuticals (antacids, analgesics, antiperspirants). Presently, there is much concern about the presence of aluminium in drinking water $[7,8]$ and its employment in water treatment processes (as coagulant) and as metal in consumer products $[5,6]$. In addition, aluminium can be leached from cooking vessels in case of storage of acidic foods [9].

There is evidence that fluoride and aluminum individually contribute to the development of different disorders. Fluoride causes detrimental effects on proteins expressed in soft tissues including the blood, brain, and liver [10] by penetrating the cell membrane [11]. Fluoride buildup in bone tissues disrupts the hematopoiesis in the bone marrow [12]. Numerous studies have demonstrated that high concentrations of aluminum are present

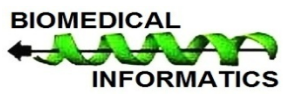




\section{Open access}

in the brains of amyotrophic lateral sclerosis and senile dementia patients $[13,14]$. The excess of both fluoride and aluminum may cause excitotoxicity through microglial activation and induce neurotoxicity [15]. The Blood Brain Barrier (BBB)-inhibits passive diffusion-is susceptible to fluoride and aluminum. Aluminum, as well as aluminum fluoride $\left(\mathrm{AlF}_{3}\right)$, can react with oxygen to form aluminum oxide $\left(\mathrm{Al}_{2} \mathrm{O}_{3}\right)$, which is found in significant amount in the brain specimen of Alzheimer patients [16]. $\mathrm{AlF}_{3}$ also substantiates osteoporosis, osteomalacia, spontaneous bone fractures, and dementia [17]. Identified protein targets for fluoride and aluminum in this analysis are involved in various important biological functions, for instance, PPP3CC has a role in the apoptotic signaling pathway, FGF12 is involved in nervous system development, etc. Data-driven prediction tools are used to screen for the targets. However, In vitro experiments are warranted to validate the finding in this study.

\section{Methodology:}

Network analysis/ retrieval:

The first step in the prediction of the potential protein targets of fluoride and aluminum is to find the network of interacting proteins with $\mathrm{F}^{-}$and $\mathrm{Al}^{3+}$ ions in human. We have used the STITCH 5.0 (Search Tool for Interacting Chemicals) (http://stitch.embl.de/) web server to find the protein targets. The STITCH database aims to incorporate dispersed databases, texts, and prediction methods into a single, easy-to-use resource. The STITCH offers a comprehensive overview of chemical and protein interaction network for numerous organisms including binding affinities between them. The predicted interaction is global for an individual organism and does not distinguish tissue specificity [18]. Target proteins from the STITCH were then subjected to the STRING (Search Tool for the Retrieval of Interacting Genes/Proteins) analysis to identify protein-protein association network. The STRING 10.5 (https://stringdb.org/) database goals to combine physical and functional interactions between proteins from a diverse source, including literature mining, experimental data, and computational prediction [19].

\section{Retrieving the protein sequences:}

The protein sequences identified with the STRING 10.5 analysis were downloaded in FASTA format from NCBI protein database (http://www.ncbi.nlm.nih.gov/protein). Two FASTA files were downloaded, containing 86 and 90 proteins for fluoride and aluminum, respectively. Additionally, numerous data-driven tools further analyzed these proteins.

\section{Gene ontology analysis:}

Gene ontology (GO) of the retrieved protein sequences was analyzed by Blast 2 GO software (https://www.blast2go.com/) [20]. This tool provides a high-throughput functional annotation for gene product properties [21]. We have utilized the aforementioned tool to identify the association between the target proteins and with the ions in the biological processes, molecular function, and cellular component of the human.

\section{Identficication of common proteins:}

The Venny 2.1 (http://bioinfogp.cnb.csic.es/tools/venny/) web server [22] has been used to identify 19 common protein targets from the list of proteins mentioned above.

\section{Analysis of expression of common proteins:}

The organs expressing the 19 common genes and their expression level have been determined from the NCBI (https://www.ncbi.nlm.nih.gov/gene/) database that uses RPKM (Reads Per Kilo-base per Million mapped reads) to quantify gene expression level.

\section{Results:}

\section{Interaction prediction:}

The STITCH 5.0 predicts the association for ion-protein network and their binding affinities. The STITCH 5.0 has predicted 20 human proteins for fluoride and aluminum interaction (10 proteins for each) (Figure 1). The STRING 10.5 predicts the network for protein-protein interaction. The STRING 10.5 has found 86 human proteins that interact with proteins predicted by the STITCH for fluoride and 90 for aluminum (Table 1 and 2).

\section{Pathway detection:}

Through the Blast 2 GO software, we executed a series of steps for a list of target protein sequences of fluoride and aluminum, including protein Blast, mapping, and scanning motifs by Inter Pro Scan. The Gene Ontology (GO) has been performed to annotate the biological processes, molecular function, and cellular component for all the proteins found by the STITCH 5.0 and STRING 10.5 (Figure 2-4), and for 19 common proteins detected by the Venny web server (Figure 6).

\section{Common Targets Determination:}

The Venny 2.1 web server has been used to detect the 19 common protein targets of fluoride and aluminum (Table 3 and Figure 5).

Table 1. List of all proteins that directly and indirectly interact with fluoride. Analyzed by STITCH 5.0 and STRING 10.5 tools.

\begin{tabular}{|c|c|c|c|c|c|c|c|c|c|c|}
\hline STITCH & CALM1 & CALM2 & BCHE & AQP6 & NUDT3 & BGLAP & GAPDH & TP53 & ENO2 & ATP11A \\
\hline & NOS2 & CAMK2A & CHRNA4 & GK & MGAM & SPP1 & ALDOC & CDKN2A & PGAM4 & WDTC1 \\
\hline \multirow[t]{4}{*}{ STRING } & NOS3 & САМК2B & CHAT & GK5 & RPS10 & BMP2 & PGK1 & MDM2 & PGAM1 & АТР7B \\
\hline & РРРЗСВ & CAMK2G & F2 & GPD2 & & TBP & BPGM & BAX & PGK1 & ATP1A3 \\
\hline & РРРЗСС & SPTAN1 & ALB & GK2 & & RUNX2 & PGK2 & BCL2 & PGK2 & ATP6V1A \\
\hline & CAMK2A & SCN10A & $\mathrm{APP}$ & AQP10 & & IBSP & ENO1 & CREBP & PKM & DNAH8 \\
\hline
\end{tabular}

ISSN 0973-2063 (online) 0973-8894 (print) 


\section{BIOINFORMATION \\ Discovery at the interface of physical and biological sciences}

Open access

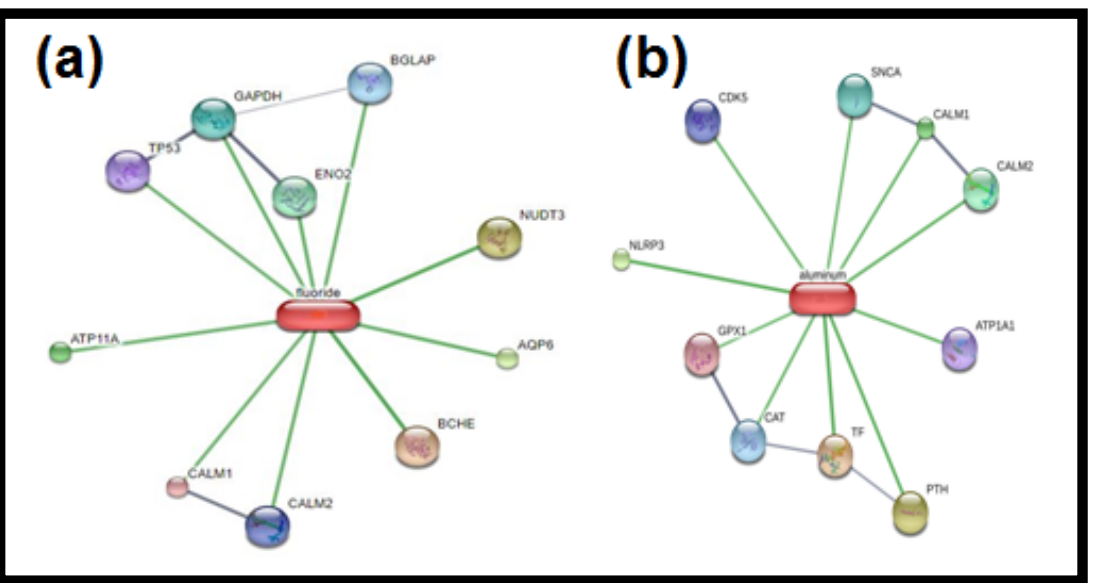

Figure 1. The network of interactions of (a) fluoride and (b) aluminum with protein targets predicted by STITCH 5.0. Fluoride and aluminum are represented as pill-shaped nodes, while proteins are shown as spheres. Nodes that are associated with each other are linked by an edge. The line's length refers to the binding affinities with each other. Greater affinity means shorter edge between the chemicals and the proteins and vice versa.

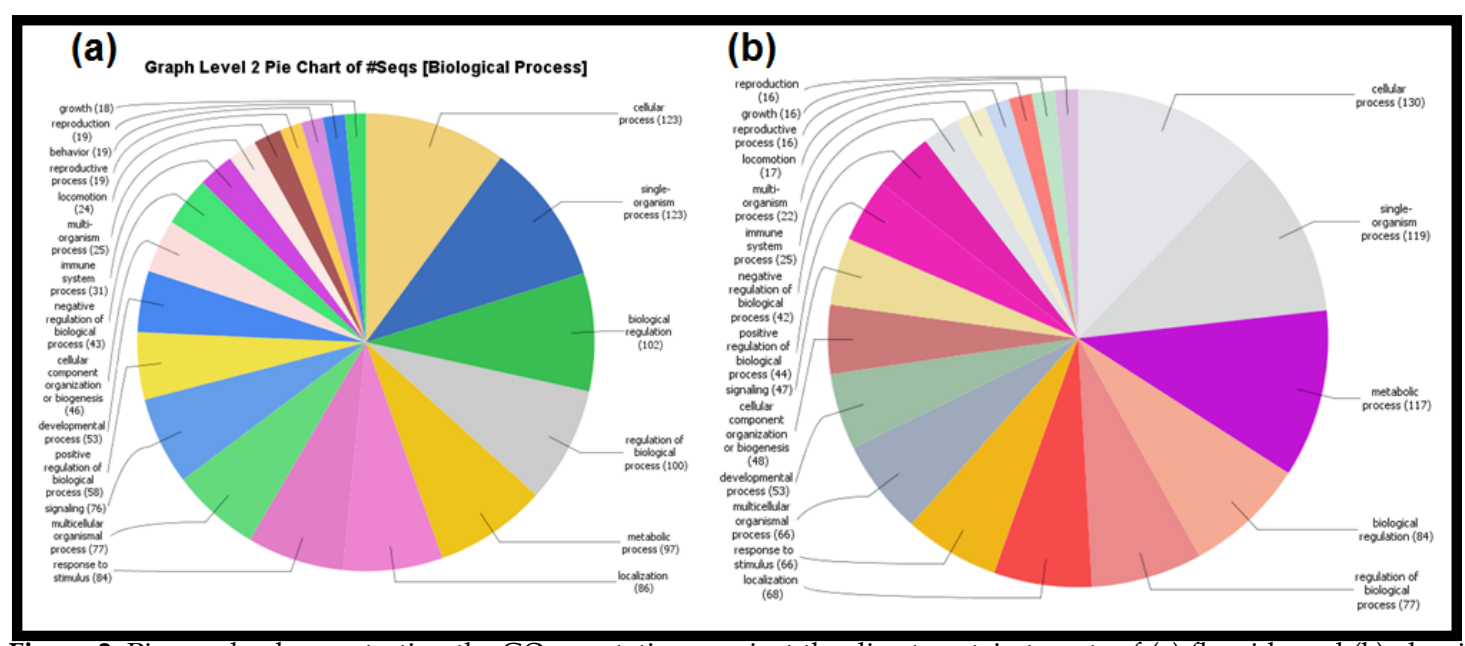

Figure 2. Pie graphs demonstrating the GO annotations against the direct protein targets of (a) fluoride and (b) aluminum. The diagrams represent the involvement of the proteins in the biological processes in human. The numbers in the parentheses represent how many GO annotations are present in each different biological process. Results are based on the Blast2GO data mining.

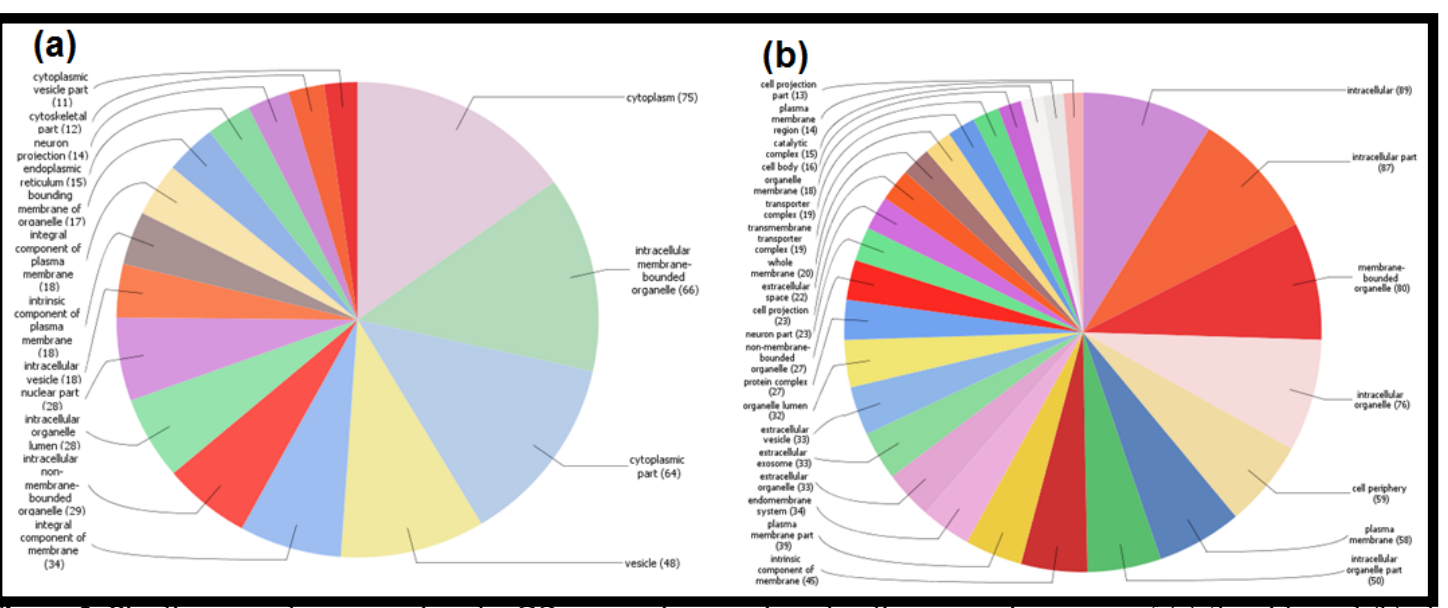

Figure 3. Pie diagrams demonstrating the $\mathrm{GO}$ annotations against the direct protein targets of (a) fluoride and (b) aluminum. The charts represent the association of the proteins in the molecular functions in human. The numbers in the parentheses represent how many GO annotations are present in each different molecular function. Results are based on the Blast2GO data mining.

ISSN 0973-2063 (online) 0973-8894 (print)

Bioinformation 14(2): 68-74 (2018) 


\section{Open access}

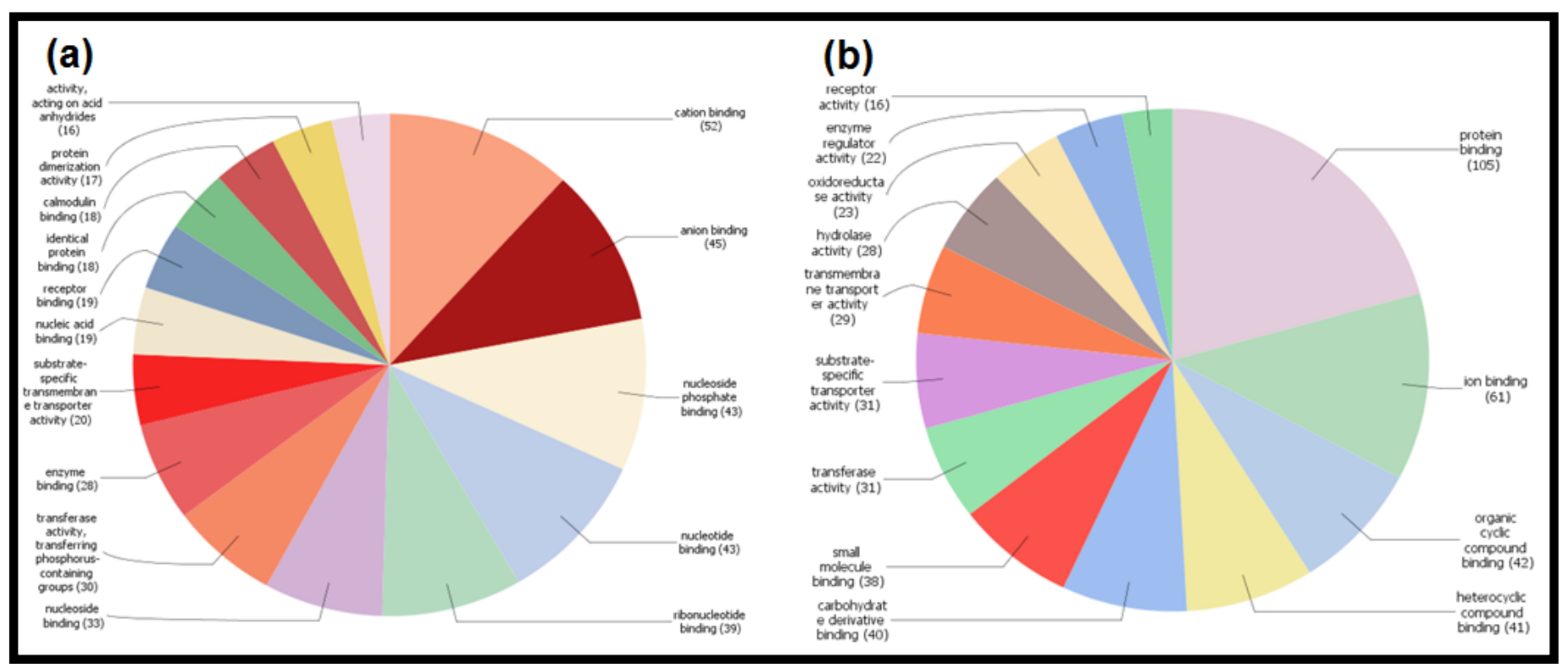

Figure 4. Pie charts demonstrating the GO annotations against the direct protein targets of (a) fluoride and (b) aluminum. The diagrams represent the involvement of the proteins in the cellular components in human. The numbers in the parentheses represent how many GO annotations are present in each different cellular component. Results are based on the Blast2GO data mining.

Table 2. List of all proteins that directly and indirectly interact with aluminum. Analyzed by STITCH 5.0 and STRING 10.5 tools.

\begin{tabular}{|c|c|c|c|c|c|c|c|c|c|c|}
\hline STITCH & CALM1 & CALM2 & ATP1A1 & PTH & TF & CAT & GPX1 & NLRP3 & CDK5 & SNCA \\
\hline \multirow{10}{*}{ STRING } & MYLK & FGF12 & FXYD4 & PTH2 & TFR2 & ALDH3A2 & GSTT2B & TXNIP & CABLES1 & UCHL1 \\
\hline & NOS1 & РPР3СA & FXYD6 & CALCA & HFE & HAO1 & GSTP1 & BRE & MAPT & UBB \\
\hline & NOS2 & CAMK2A & FXYD7 & AVP & ALB & $\mathrm{HAO} 2$ & GSTT1 & IL1B & DPYSL2 & SIAH2 \\
\hline & NOS3 & CAMK2B & FXYD2 & SCT & CFTR & ALDH2 & GSTM1 & AIM2 & CDK5R1 & SNCAIP \\
\hline & РРРЗСА & NOS3 & FXYD1 & PTH1R & EGF & SOD2 & GSR & NLRC4 & PPP1R1B & PARK2 \\
\hline & РРР3СВ & CAMK2G & FXYD3 & PTH2R & EGFR & AKT1 & GSS & PYCARD & CDK5R2 & PARK7 \\
\hline & РРР3СС & SPTAN1 & ATP1B1 & SCTR & АРОВ & SOD3 & HPGDS & CARD8 & CDK5R1 & SLC6A3 \\
\hline & CAMK2A & SCN10A & ATP1B2 & NPSR1 & RAB5A & SOD1 & SOD1 & CASP1 & NDEL1 & KLK6 \\
\hline & CAMK2B & SCN11A & ATP1B3 & GCG & M6PR & PRDX1 & SOD2 & CASP5 & CCNB1 & APP \\
\hline & CAMK2G & SCN5A & ATP1B4 & PTHLH & TFRC & GSR & SOD3 & NLRP1 & CCNB2 & FYN \\
\hline
\end{tabular}

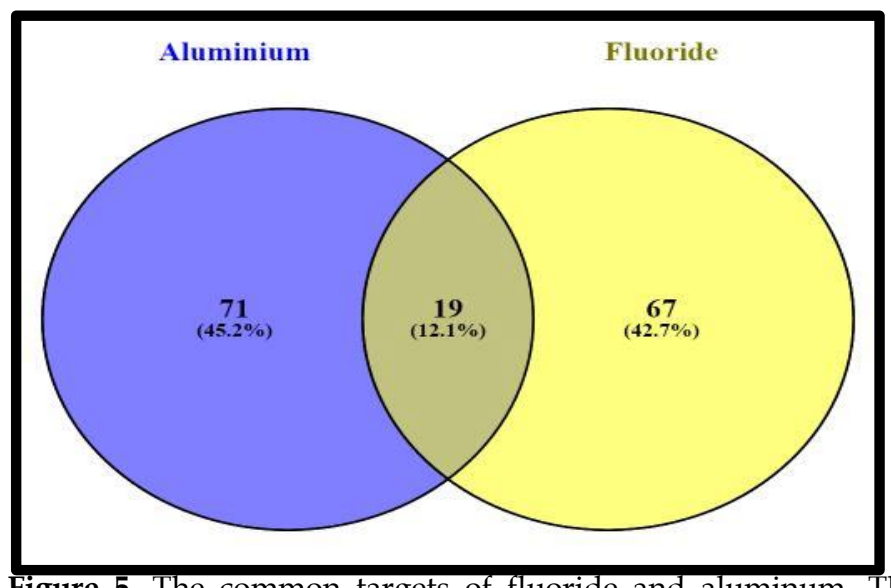

Figure 5. The common targets of fluoride and aluminum. The number in the Venn diagram (overlapping portion) represents the common targets. Analyzed by Venny web server.
Table 3. Expression site and expression level of common 19 target proteins on the basis of their RPKM

\begin{tabular}{|c|c|c|}
\hline Protein & Organ & RPKM \\
\hline MYLK & Prostate & $187.535 \pm 50.564$ \\
\hline NOS1 & Brain & $1.116 \pm 0.49$ \\
\hline NOS2 & Small intestine & $10.258 \pm 12.184$ \\
\hline NOS3 & Spleen & $28.438 \pm 5.532$ \\
\hline РРРЗСА & Brain & $54.022 \pm 15.795$ \\
\hline РРРЗСВ & Brain & $40.219 \pm 13.441$ \\
\hline РРРЗСС & Testis & $12.255 \pm 3.702$ \\
\hline CAMK2A & Brain & $112.156 \pm 36.88$ \\
\hline CAMK2B & Brain & $44.021 \pm 23.5$ \\
\hline CAMK2G & Brain & $28.686 \pm 4.302$ \\
\hline FGF12 & Heart & $20.774 \pm 12.935$ \\
\hline SPTAN1 & Brain & $87.712 \pm 17.558$ \\
\hline SCN10A & Testis & $0.0088 \pm 0.054$ \\
\hline SCN11A & Spleen & $1.852 \pm 0.559$ \\
\hline SCN5A & Heart & $17.627 \pm 3.827$ \\
\hline ATP1B2 & Brain & $126.89 \pm 28.341$ \\
\hline ATP1B3 & Adrenal & $108.403 \pm 49.947$ \\
\hline ALB & Liver & $41385.4 \pm 9345.518$ \\
\hline APP & Brain & $395.222 \pm 72.782$ \\
\hline
\end{tabular}

ISSN 0973-2063 (online) 0973-8894 (print)

Bioinformation 14(2): 68-74 (2018) 
(a)

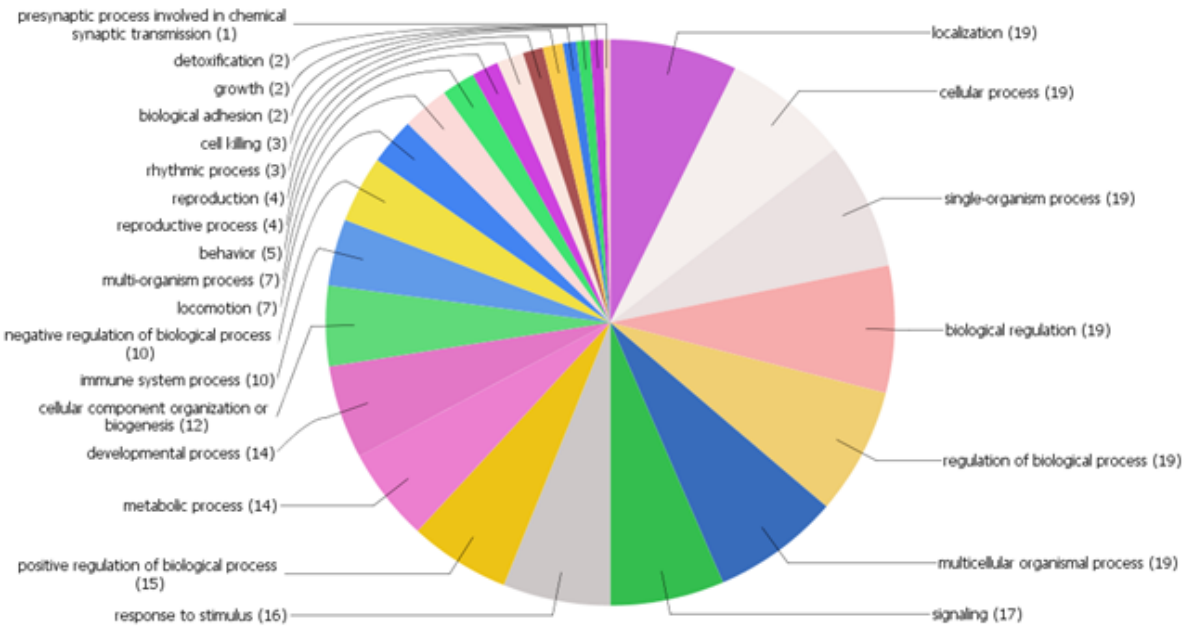

(b)

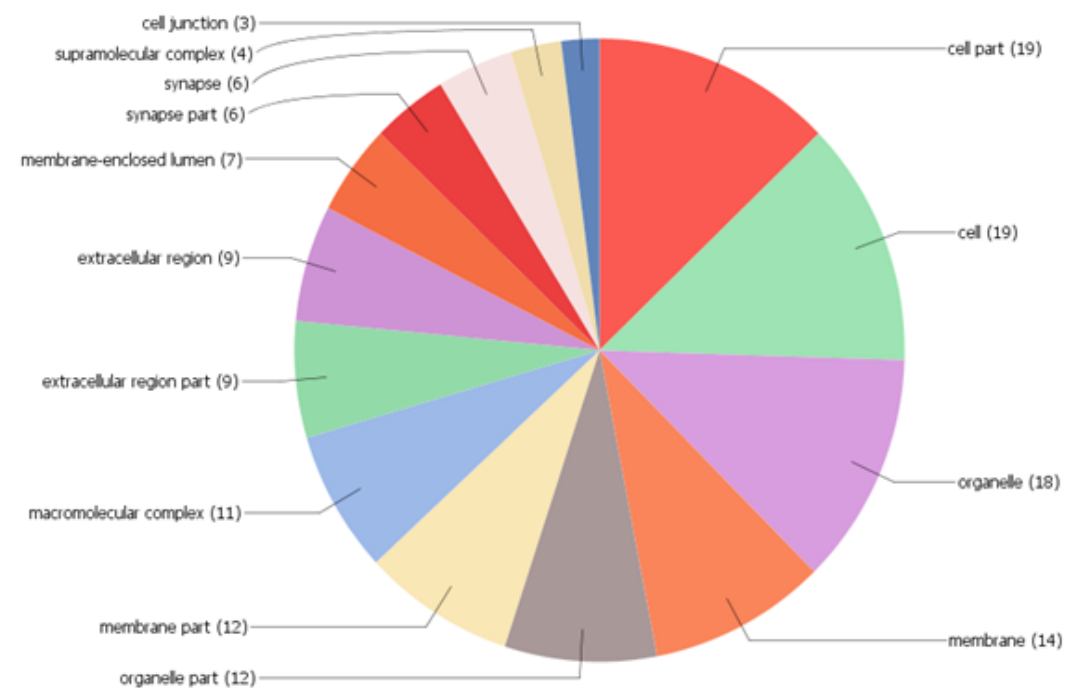

(c)

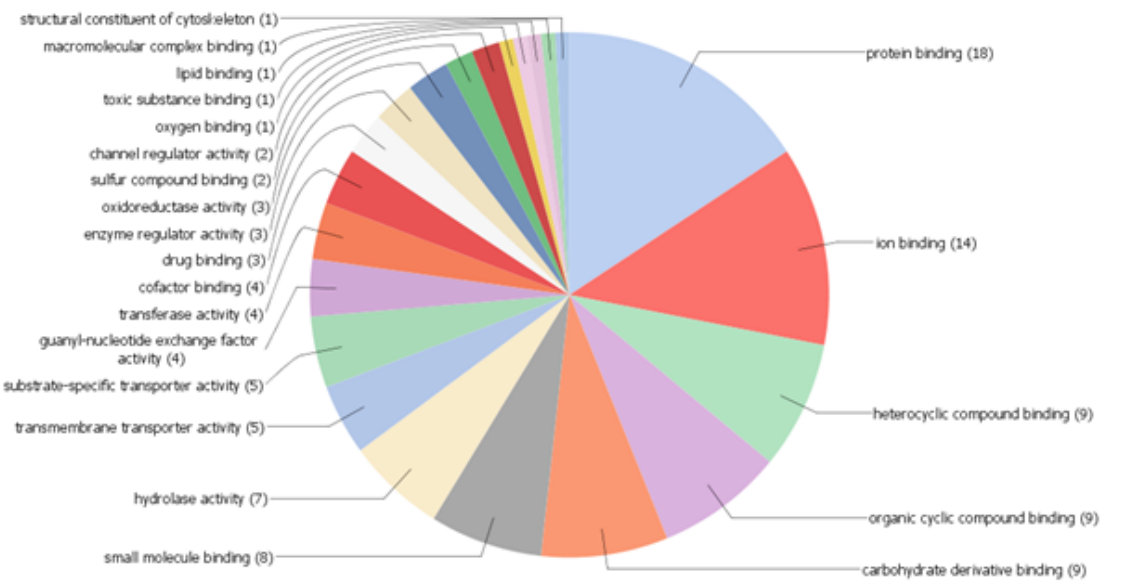

Figure 6. Pie diagrams demonstrating the GO annotations against the common protein targets of fluoride and aluminum. The charts represent the association of the proteins in the (a) biological processes, (b) cellular components, and (c) molecular functions in human. The numbers in the parentheses represent how many GO annotations are present in each different cellular processes. Results are based on the Blast2GO data mining.

ISSN 0973-2063 (online) 0973-8894 (print) 
Table 4. A short description of the common binding targets of $\mathrm{F}-$ and $\mathrm{Al}$ with their normal physiological functions.

\begin{tabular}{|c|c|c|c|}
\hline Name & Short description & Functions & Reference \\
\hline \multirow[t]{2}{*}{ MYLK } & Myosin light chain kinase & $\begin{array}{l}\text { Implicated in smooth muscle contraction via phosphorylation of myosin light chains. } \\
\text { Involved in inflammatory response and cell migration. Pseudogene of MYLK found } \\
\text { having carcinogenic effect. }\end{array}$ & [23] \\
\hline & Nitric oxide synthase 1 (neuronal) & $\begin{array}{l}\text { Process involved in neurotransmitter biosynthesis and secretion. Polymorphism in } \\
\text { this gene has association with neurological disorder and asthma. }\end{array}$ & [24] \\
\hline \multicolumn{4}{|c|}{ o } \\
\hline \multirow[t]{2}{*}{ NOS2 } & Nitric oxide synthase 2 (inducible) & $\begin{array}{l}\text { Nitric oxide-mediated cell signaling pathway and variation found in asthma } \\
\text { patients. }\end{array}$ & [25] \\
\hline & Nitric oxide synthase 3 (endothelial cell) & $\begin{array}{l}\text { Vascular smooth muscle relaxation through a cGMP-mediated signal transduction } \\
\text { pathway has association with variation in this gene has association with asthma and }\end{array}$ & [26] \\
\hline NOS3 & & Alzheimer disease. & \\
\hline PPP3CA & $\begin{array}{l}\text { Protein phosphatase } 3 \text {, catalytic subunit, } \\
\text { alpha isozyme }\end{array}$ & Calcium ion transport, calcinurin-NFAT signaling cascade & [27] \\
\hline РРР3СВ & $\begin{array}{c}\text { Protein phosphatase } 3 \text {, catalytic subunit, beta } \\
\text { isozyme }\end{array}$ & $\begin{array}{l}\text { Calcineurin-NFTA signaling cascade, regulate synaptic spacticity has an association } \\
\text { with schizophrenia. }\end{array}$ & [28] \\
\hline РPР3СC & $\begin{array}{c}\text { Protein phosphatase } 3 \text {, catalytic subunit, } \\
\text { gamma isozyme }\end{array}$ & Role in apoptotic signaling pathway has association with schizophrenia. & [29] \\
\hline CAMK2A & $\begin{array}{l}\text { Calcium/calmodulin dependent protein } \\
\text { kinase II alpha }\end{array}$ & $\begin{array}{l}\text { Role in the regulation of synaptic plasticity. Mutation in this gene result in } \\
\text { neurological disorder. }\end{array}$ & [30] \\
\hline \multirow[t]{2}{*}{ CAMK2B } & $\begin{array}{l}\text { Calcium/calmodulin-dependent protein } \\
\text { kinase II beta }\end{array}$ & Regulation of calcium ion transport and synapse structural plasticity. & [31] \\
\hline & $\begin{array}{l}\text { Calcium/calmodulin-dependent protein } \\
\text { kinase II gamma }\end{array}$ & $\begin{array}{l}\text { Involved in sarcoplasmic reticulum } \mathrm{Ca}^{2+} \text { transport in skeletal muscle and may } \\
\text { function in dendritic spine, synapse formation, and neuronal plasticity. }\end{array}$ & [32] \\
\hline CAMK2G & Fibroblast growth factor 12 & Involved in nervous system development and function & [33] \\
\hline FGF12 & Spectrin, alpha, non-erythrocytic 1 & Calcium-dependent movement of the cytoskeleton at the membrane & [34] \\
\hline \multirow[t]{2}{*}{ SCN10A } & $\begin{array}{c}\text { Sodium channel, voltage-gated, type } \mathrm{X} \text {, alpha } \\
\text { subunit }\end{array}$ & Mediates the voltage-dependent sodium ion permeability of excitable membranes & [35] \\
\hline & $\begin{array}{l}\text { Sodium channel, voltage-gated, type XI, } \\
\text { alpha subunit }\end{array}$ & $\begin{array}{l}\text { Encodes Nav1.9, a voltage-gated sodium ion channel which functions as key relay } \\
\text { stations for the electrical transmission of pain signals from the periphery to the } \\
\text { central nervous system }\end{array}$ & [36] \\
\hline SCN5A & $\begin{array}{c}\text { Sodium channel, voltage-gated, type } \mathrm{V}, \\
\text { alpha subunit }\end{array}$ & Responsible for the initial upstroke of the action potential & [37] \\
\hline ATP1B2 & $\begin{array}{l}\text { ATPase, } \mathrm{Na}^{+} / \mathrm{K}^{+} \text {transporting, beta } 2 \\
\text { polypeptide }\end{array}$ & $\begin{array}{l}\text { Catalyzes the hydrolysis of ATP coupled with the exchange of } \mathrm{Na}^{+} \text {and } \mathrm{K}^{+} \text {ions } \\
\text { across the plasma membrane }\end{array}$ & [38] \\
\hline ATP1B3 & $\begin{array}{l}\text { ATPase, } \mathrm{Na}^{+} / \mathrm{K}^{+} \text {transporting, beta } 3 \\
\text { polypeptide }\end{array}$ & $\begin{array}{l}\text { Catalyzes the hydrolysis of ATP coupled with the exchange of } \mathrm{Na}^{+} \text {and } \mathrm{K}^{+} \text {ions } \\
\text { across the plasma membrane }\end{array}$ & [39] \\
\hline ALB & Serum albumin, the main protein of plasma & Regulating the colloidal osmotic pressure of blood & [40] \\
\hline $\mathrm{APP}$ & Amyloid beta (A4) precursor protein & $\begin{array}{l}\text { Triggering caspase activation and degeneration of both neuronal cell bodies and } \\
\text { axons }\end{array}$ & [41] \\
\hline
\end{tabular}

\section{Discussion:}

Our findings suggest that fluoride and aluminum both have direct (ion-protein interaction) and indirect (protein-protein interaction) protein targets in the human. They directly bind with 20 proteins (both have 10 targets each), while the indirect binding network has 86 and 90 proteins for fluoride and aluminum, respectively. They have different binding affinities with their target, for instance, fluoride has a strong binding affinity with ENO2 compared to GAPDH and aluminum can strongly bind with GPX1 compared to SNCA. The GO annotation for the identified proteins demonstrates their association with numerous biological processes, cellular components, and molecular functions in the human. Both the ions have 19 common protein targets. We have further analyzed their expression site and expression level. RPKM data shows different expression level of the common target proteins of fluoride and aluminum in the human, for example, ALB (albumin) is highly expressed in the liver and SCN10A (Sodium Channel 10 Alpha subunit) is barely expressed in the testis. Most of the common target proteins are expressed in the brain. Fluoride and aluminum could have detrimental effects on many organs, including the spleen, liver, adrenal and prostate glands, small intestine, heart, and primarily ISSN 0973-2063 (online) 0973-8894 (print)

Bioinformation 14(2): 68-74 (2018) the brain. The accumulation of aluminum-fluoride $\left(\mathrm{AlF}_{3}\right)$ complex in the brain causes prolonged neurotoxicity, synaptic loss, and neurodegeneration [44]. $\mathrm{AlF}_{3}$ complex is able to impair the energy-producing enzymes; free radical balances, lipid peroxidation, and DNA repair mechanism [45, 46]. The target proteins are involved in different important functions, including programmed cell death, nervous system development, osmotic blood pressure regulation, action potential generation, etc. More importantly, most of the target proteins are brain-specific; therefore, chronic exposure to these ions could lead to the development of neurological disorders. One recent study showed that $\mathrm{Al}^{3+}$ could play a vital role as a mediator in the formation of fibrillary amyloid plaques in Alzheimer's disease [48].

Here, we find that APP or Amyloid beta (A4) precursor protein can interact with $\mathrm{F}^{-}$and $\mathrm{Al}^{3+}$. APP is a single-pass transmembrane protein highly expressed in the brain and is a key factor in the development of Alzheimer's disease [46]. It is possible that other target proteins of $\mathrm{F}^{-}$and $\mathrm{Al}^{3+}$ are associated with different diseases. However, further studies must be warranted to validate the binding network and to distinguish the physiologically important and unimportant bindings. 


\section{Conclusion:}

Effects of fluoride and aluminum on living organisms especially on the humans come to light through long-term exposure to these ions. To minimize the exposure to fluoride and aluminum, public awareness is a must, for instance, parents should pay close attention to their children while they brush their teeth. In addition, companies should make toothpaste tasteless. We should avoid boiling the water in aluminum vessels, preserving acidic fruits and vinegar in the aluminum containers, preparing acidic fruit juice in the aluminum coated juicer, and use of automatic coffee machines etc. [47] to lower human exposure. Moreover, public policy, rules, and regulation should be implemented to minimize the exposures.

\section{Conflict of Interest:}

The authors have declared that no competing interest exists.

\section{Acknowledgements:}

The authors are grateful to the Department of Biochemistry and Molecular Biology, University of Dhaka, Bangladesh and Department of Biological Sciences, St. John's University, Queens, New york, United States.

\section{References:}

[1] Sprando R et al. Food Chem Toxicol. 1998, 36:1117. [PMID: 9862654]

[2] Yadav AK et al. J. Hazard. Mater. 2007, 142:77. [PMID: 16979289]

[3] Sargazi M et al. J. Inorg. Biochem. 2001, 87:37. [PMID: 11709211]

[4] Ochmański W \& Barabasz W. Przegl Lek. 2000, 57:665. [PMID: 11293216]

[5] Havas M \& Jaworski JF. Subcommittee on Heavy Metals and Certain Other Elements. 1986.

[6] Cech I \& Montera J. Water Res. 2000, 34:2703.

[7] Blaylock RL. Curr. Inorg. Chem. 2012, 2:46.

[8] Liukkonen-Lilja H \& Piepponen S. Food Addit. Contam. 1992, 9:213.

[9] Mullenix PJ et al. Neurotoxicol. Teratol. 1995, 17:169. [PMID: 7760776].

[10] Carlson CH et al. Proc. Soc. Exp. Biol. Med. 1960, 104:235. [PMID: 13855628]

[11] Zejmo M et al. B. International Society for Fluoride Research. 2000, 33.

[12] Becaria A et al. Toxicol. Ind. Health. 2002, 18:309. [PMID: 15068131]

[13] Perl DP et al. Science. 1982, 217:1053. [PMID: 7112111]

[14] Niu Q et al. Neurotox. Res. 2007, 12:163. [PMID: 17967740]

[15] Blaylock RL. Fluoride. 2004, 37:301.

[16] Akinrinade ID et al. Pathophysiology. 2015, 22:105. [PMID: 25863844]

Citation: Hasan et al. Bioinformation 14(2): 68-74 (2018) License statement: This is an Open Access article which permits unrestricted use, distribution, and reproduction in any medium, provided the original work is properly credited. This is distributed under the terms of the Creative Commons Attribution License
[17] Li Fu-cheng et al. Endemic diseases bulletin. 1989, 4:57.

[18] Szklarczyk D et al. Nucleic Acids Res. 2016, 44:D380. [PMID: 26590256]

[19] Szklarczyk D et al. Nucleic Acids Res. 2017, 45:D362. [PMID: 27924014]

[20] Conesa A et al. Bioinformatics. 2005, 21:3674. [PMID: 16081474]

[21] Gotz S et al. Nucleic Acids Res. 2008, 36:3420. [PMID: 18445632]

[22] http:// bioinfogp.cnb.csic.es/tools/venny/

[23] Han YJ et al. FASEB J. 2011, 25:2305. [PMID: 21441351]

[24] Shinkai T et al. Mol. Psychiatry. 2002, 7:560. [PMID: 25404897]

[25] Gao PS et al. Biochem. Biophys. Res. Commun. 2000, 267:761. [PMID: 17189532]

[26] Takimoto E et al. Circ. Res. 2005, 96:100. [PMID: 19822814]

[27] Wang MG et al. Cytogenet. Genome Res. 1996, 72:236. [PMID: 8978785]

[28] Liu CM et al. Biol. Psychiatry. 2011, 70:51. [PMID: 21531385]

[29] Liu YL et al. Mol. Psychiatry. 2007, 12:966. [PMID: 17339875]

[30] Stephenson JR et al. J. Neurosci. 2017, 37:2216. [PMID: 28130356]

[31] Wayman GA et al. Neuron. 2008, 59:914. [PMID: 18817731]

[32] Gloyn AL et al. Diabetologia. 2002, 45:580. [PMID: 12032636]

[33] Hartung H et al. Mech. Dev. 1997, 64:31. [PMID: 9232594]

[34] Writzl K et al. Epilepsia. 2012, 53:e106. [PMID: 22429196]

[35] Chambers JC et al. Nat. Genet. 2010, 42:149. [PMID: 20062061]

[36] Leipold E et al. Nat. Genet. 2013, 45:1399. [PMID: 24036948]

[37] Splawski I et al. Science. 2002, 297:1333. [PMID: 12193783]

[38] Wang $Z$ et al. Mol. Biol. Rep. 2011, 38:1749. [PMID: 20842439]

[39] McMahon FJ et al. Am. J. Hum. Genet. 1997, 61:1397. [PMID: 9399888]

[40] He XM \& Carter DC. Nature. 1992, 358:209. [PMID: 1630489]

[41] Wilquet V \& De Strooper B. Curr. Opin. Neurobiol. 2004, 14:582. [PMID: 15464891]

[42] O'Brien RJ \& Wong PC. Annu. Rev. Neurosci. 2011, 34:185. [PMID: 21456963]

[43] Levy SM \& Guha-Chowdhury N. J. Public Health Dent. 1999, 59:211. [PMID: 10682326]

[44] Blaylock RL. Surg Neurol. 2011, 2:107 [PMID: 21886880]

[45] O'Brien RJ \& Wong PC. Annu. Rev. Neurosci. 2011, 34:185. [PMID: 21456963]

[46] Levy SM \& Guha-Chowdhury N. J. Public Health Dent. 1999, 59: 211. [PMID: 10682326]

[47] Liukkonen-Lilja H \& Piepponen S. Food Addit. Contam. 1992, 9:213. [PMID: 1397396]

[48] Zhang Q et al. Arabian J. Chem. 2015.

Edited by $P$ Kangueane 